\title{
Actors and Creators: Analyzing the roles played by various stakeholders in exploratory projects in Multinational Companies
}

\author{
Khalil Oudah $^{\mathrm{a}}$, Khalid Almarri ${ }^{\mathrm{b}}$ \\ a,b The British University in Dubai, Project Management Department, Faculty of Business and Law, PO Box 345015, Dubai, United Arab Emirates.
}

Correspondence Author: Dr Khalid Almarri, The British University in Dubai, Project Management Department, Faculty of Business and Law, PO Box 345015, Dubai, United Arab Emirates.

Received date: 15 July 2019, Accepted date: 28 September 2019, Online date: 30 September 2019

Copyright: () 2019 Khalil Oudah \& Khalid Almarri, This is an open-access article distributed under the terms of the Creative Commons Attribution License, which permits unrestricted use, distribution, and reproduction in any medium, provided the original author and source are credited.

\begin{abstract}
Project management which was traditionally associated with academics and professionals is now an integral part of organizational research. Novelty, execution and performance of projects are increasingly depended on contributions of research. Exploratory research is vital in organizational project management and the current study analyzes the roles of various stakeholders within its gamut. The study collected both quantitative and qualitative data from around 500 employees of 10 multinational companies, working in project management and related activities within these companies. The empirical research highlights the duration and processes of exploratory projects within the organizational working cycle across various industries.
\end{abstract}

Keywords: Exploratory research, project management, stakeholders, multinational companies.

\section{INTRODUCTION}

Technology, The institution of business and organization, is becoming diverse and complex with each passing decade. Business practices, product development, strategic planning is now increasingly dependent on researches to gain competitive advantage and expand customer base. Thus, the field of project management has turned intricate and multifaceted. For long this field has been associated with mathematics, optimization theory and application engineering. However, the global economic platform propelled the interest of other academic fields and business houses towards project management and its associated research activities. Project management is described as the activity through which financial and human resources are arranged and mobilized towards certain organizational objectives within the constraints of time and cost (Heagney, 2016). Research in project management contributes to project innovation, execution, and performance. The current internet era places greater emphasis on organizational learning and knowledge management which have intense research background and requirement (Morris, 2010). Another important aspect of project management is the identity and roles of stakeholders. Stakeholders are people or community that are associated with the project to at various levels and to various degrees. They impact the project and get affected in return (Peter, 2015). The role of stakeholders in project management exploratory research is a new topic that was not discussed previously in academia or business terms. Therefore, this research study aims at recognizing the stakeholders of exploratory research projects and analyses the roles and responsibilities of these stakeholders in the various project management activities.

\section{Research Aim:}

The primary aim of the current study is to analyze the various roles played by different stakeholders associated with exploratory project management in multinational companies.

\section{Research Objectives:}

- To analyze the state of project management research in larger corporations with a global presence

- To evaluate the various elements associated with project management research

- To analyze exploratory research practices in project management of multinational companies

- To assess and distinguish the stakeholders of project management associated with exploratory research

- To analyze the roles and responsibilities of stakeholders of exploratory projects of multinational companies. 
Citation: Oudah \& Almarri., Application of Blockchain Technology for Secure Data Transactions in Organizations. Australian Journal of Basic and Applied Sciences, 13(9): 54-65. DOI: 10.22587/ajbas.2019.13.9.6

\section{LITERATURE REVIEW}

\section{Project Management in Multinational Companies}

Ahmed \& Anantatmula (2017) analyzed the implications of the leadership style of project managers on project management and performance of projects. Their study applied several quantitative data techniques that include exploratory and confirmatory factor analysis and regression analysis to the collected data. The study concluded that leadership competencies have significant impact on multiple variables of project performance such as project schedule, project quality, project cost and the satisfaction of stakeholders from project results. The five leadership competencies the study focused on are roles and responsibilities of project managers, communication of expectations, employment of consistent processes, clarity in communication and the establishment of trust. Aubry et. al (2012) researched on project management practices as organizational functions. The study hypothesized that the organizational functions related to project management are: transforming and implementing corporate strategies into projects, programs, and portfolios for the company, facilitating coordination between various interconnected projects of the company and laying out the foundation for future research in project management. A mixed methodology was adopted in this study where the result pointed towards various major organizational project management functions. Culture is an essential aspect of organizational project management. The research also postulated that in a monopolistic market, employees exhibit better competency and acquire better skills for project completion. The study highlighted the importance of dynamic processes in project management such as active maintenance of project activities and cohesion between organizational objectives and project management implementation. However, the study was limited to only one single organization without any further study towards the reliability and validation of results.

Siriram (2018) evaluated seventy-five project management assessments to compare and analyze the project management practices of various companies. The comparative analysis was carried out for four companies across four industries. The study found information and communication technology and electronics and electrical engineering had significant differences in project management practices. However, service and consulting engineering exhibited no difference in project management practices and overall results. The enumerated sixteen project management constructs which were grouped into three categories. Table 1 represents the project management assessment constructs as listed by Siriram (2018).

Table 1: Project Management Assessment (PMA) constructs (Siriram, 2018)

\begin{tabular}{|c|c|c|}
\hline SI. No. & Grouping & Project management practices metrics \\
\hline 1 & \multirow[t]{4}{*}{ Project Organization } & Project management agreement \\
\hline 2 & & $\begin{array}{l}\text { Project user requirements specifications (BRS) clearly } \\
\text { specified and signed off by the necessary stakeholders }\end{array}$ \\
\hline 3 & & Behaviors of executives \\
\hline 4 & & Project Controlling \\
\hline 5 & \multirow[t]{5}{*}{ Risk and Variation } & Risk management \\
\hline 6 & & Change management-project scope creep and variation \\
\hline 7 & & $\begin{array}{l}\text { Customer satisfaction and satisfaction of other interest } \\
\text { groups }\end{array}$ \\
\hline 8 & & Employee satisfaction \\
\hline 9 & & $\begin{array}{l}\text { Project organization- project organizational structure, } \\
\text { involvement of correct stakeholders, regular project } \\
\text { meetings, distribution of minutes of meetings etc. }\end{array}$ \\
\hline 10 & \multirow{7}{*}{$\begin{array}{l}\text { Project planning, } \\
\text { engineering design, } \\
\text { and quality }\end{array}$} & Schedule/resource/project milestones/procurement planning \\
\hline 11 & & Project communication and escalation \\
\hline 12 & & $\begin{array}{l}\text { Project management process, project documentation and } \\
\text { project close off }\end{array}$ \\
\hline 13 & & Health and safety \\
\hline 14 & & Engineering design/consulting/innovation \\
\hline 15 & & Compensation and performance incentives \\
\hline 16 & & Overall result and comparison to other projects \\
\hline
\end{tabular}

Pucihar et al. (2016) conducted observational research on personal project management. Personal project management according to researchers is a type of project management paradigm where the complete responsibility of the project lies on an individual employee. The single employee may or may not be skilled enough to perform the assigned tasks. The overall project also gets influenced by the employee's techniques to project handling. The qualitative research methodology was applied by the researchers to evaluate the existing practices of project information management system for personal projects. The study found extensive use of information division and fragmentation, which helps to ease the access and the retrieval of stored information. Information related to a project is also divided into various segments and stored as core information and support information. Segmentation of 
Citation: Oudah \& Almarri., Application of Blockchain Technology for Secure Data Transactions in Organizations. Australian Journal of Basic and Applied Sciences, 13(9): 54-65. DOI: 10.22587/ajbas.2019.13.9.6

input and output information, use of visuals for storytelling and overlapping of projects by facilitating reuse of common information enhances understanding of the project and recreates project context. Although the study analyzed employees from various backgrounds and different fields of expertise with multiple and distinct management practices and requirements, entire fields of project management and industries could not be taken into consideration. The complexity of the research limited the study to few respondents and few areas of project management.

\section{Identifying Stakeholders}

Jing \& Jian (2014) assessed the importance of stakeholder analysis and management in modern project management practices of Chinese companies. The study highlighted that stakeholder management is one aspect where western project management practices differ from Chinese approaches. Therefore, to understand the unique and distinct condition of project management techniques of Chinese companies the study analyzed the stakeholders associated with project management. The relationship among the stakeholders and the implications and influences of the relationships on projects were also assessed in the research through qualitative exploratory study. The respondents of the study confirmed that stakeholder satisfaction is important for projects execution and their success. Successful projects should not affect the relationship of stakeholders among themselves in negative way. Many respondents opined that team members were the major stakeholders while some considered clients to be as important to the project since they can impact the quality of the project and its success. Good relationships among team members, members of other teams within the organization and with the clients are crucial for project success as most of the time conflicts are negotiated through informal discussions rather than legal actions. Informal relationships, mutual trust, long term partnerships and effective communication are considered critical elements of project success in Chinese companies. Although the research shed some light on stakeholders of project management it is limited to relationship between project team members, projects' clients and the organization's employees. However, the study did not consider any other aspects of project management and was limited to China only.

Patanakul, Lewwongcharoen \& Milosevic (2010) conducted an empirical study on tools and techniques used in project management practices across the overall life-cycle of the project to analyze their effect on the performance of the project. The researchers used the nine project management knowledge areas identified by the Project Management Institute (PMI, 2004) and listed the project management tools and techniques for that particular project management knowledge area. The knowledge areas and tools and techniques used in project management practices are shown in table 2.

Table 2: Project Management Tools and Techniques (PMTTs) and Project Management Knowledge Areas (PMI, 2008)

\begin{tabular}{|l|l|l|}
\hline SI. No. & Knowledge areas & Project management tools and techniques \\
\hline 1 & Integration management & $\begin{array}{l}\text { Project selection, payback period, return on } \\
\text { investment, project charter }\end{array}$ \\
\hline 2 & Scope management & $\begin{array}{l}\text { WBS, quality function deployment, scope statement, } \\
\text { change request, product review, scope change } \\
\text { control, lesson learned, performance } \\
\text { measurement }\end{array}$ \\
\hline 3 & Cost management & $\begin{array}{l}\text { Cost estimating techniques, cost change control } \\
\text { system, earned value management, performance } \\
\text { measurement }\end{array}$ \\
\hline 5 & Quality management & $\begin{array}{l}\text { Benefit/cost analysis, cause-and-effect diagram, } \\
\text { flowcharting, cost of quality, control charts, Pareto } \\
\text { diagram, trend analysis, benchmarking, quality } \\
\text { audits, statistical sampling }\end{array}$ \\
\hline 6 & Time management & $\begin{array}{l}\text { CPM, GERT, PERT, Gantt charts, Monte Carlo } \\
\text { analysis, simulation, buffer management, milestone } \\
\text { charts, schedule crashing, variance analysis }\end{array}$ \\
\hline 7 & $\begin{array}{l}\text { Risk management } \\
\text { Procurement } \\
\text { management }\end{array}$ & $\begin{array}{l}\text { Risk matrix, decision tree analysis, Monte Carlo } \\
\text { analysis, SWOT analysis, checklist, and Delphi, } \\
\text { earned value management, project risk audit }\end{array}$ \\
\hline management & $\begin{array}{l}\text { Stakeholder analysis, team building activities, } \\
\text { responsibility matrix, organization charts, reward and } \\
\text { recognition systems, project team directory }\end{array}$ \\
\hline management & $\begin{array}{l}\text { Stakeholder analysis, Information retrieval systems, } \\
\text { earned value management }\end{array}$ \\
\hline $\begin{array}{l}\text { Make-or-buy analysis, statement of work, contract } \\
\text { type selection, source selection, contract change } \\
\text { control system, bidder conferences }\end{array}$ \\
\hline 5
\end{tabular}

\section{Roles and Responsibilities of Stakeholders}

Aaltonen (2010) assessed the scenario of stakeholder management in internal projects through five separate case studies. The research broadly segregated the stakeholders of organizational projects into two categories, those are local or internal stakeholders and external stakeholders. The stakeholders can be of eight types. These include Customers, Suppliers, Political Groups and Governments, Investors, Trade Associations, Employees and the Communities. The study categorized stakeholders into various categories depending on the involvement level, claim towards the project, nature of relationship with the project, position towards 
the project, roles played the project and extent of anticipation of behaviours. Table 3 represents categories of stakeholders with their definition and examples.

Table 3: Categories of Stakeholders (Aaltonen, 2010)

\begin{tabular}{|c|c|c|c|}
\hline & $\begin{array}{l}\text { Stakeholder } \\
\text { Category }\end{array}$ & Definition & Examples \\
\hline \multicolumn{4}{|c|}{ Categorization of Stakeholders based on involvement with the project } \\
\hline 1 & $\begin{array}{l}\text { Internal } \\
\text { Stakeholders }\end{array}$ & $\begin{array}{l}\text { Formal members of the } \\
\text { project involved in direct } \\
\text { activities of the project that } \\
\text { include planning, initiation, } \\
\text { and implementation. }\end{array}$ & $\begin{array}{l}\text { Owners, client, users, project managers, } \\
\text { financiers, designers, facilities managers, } \\
\text { subcontractors, process and service } \\
\text { providers, suppliers, banks, shareholders, } \\
\text { insurance companies, employees }\end{array}$ \\
\hline 2 & $\begin{array}{l}\text { External } \\
\text { Stakeholders }\end{array}$ & $\begin{array}{l}\text { Not direct members of the } \\
\text { project but are associated with } \\
\text { it. }\end{array}$ & $\begin{array}{l}\text { Local communities, potential users, local } \\
\text { government, environment groups, } \\
\text { regulators, the media, legal authorities, } \\
\text { public, community representatives, } \\
\text { regional development agencies, } \\
\text { government establishments, } \\
\text { governmental } \\
\text { organizations, landowners, universities, } \\
\text { research institutes, city councils, local } \\
\text { residents, indigenous and aboriginal } \\
\text { groups, central government departments } \\
\text { and agencies, environmentalists, labor } \\
\text { unions, unions, the environment, } \\
\text { communities, political groups, trade } \\
\text { associations, activist groups, competitors, } \\
\text { employees' families, consumer advocacy } \\
\text { groups }\end{array}$ \\
\hline
\end{tabular}

Categorization of Stakeholders based on position towards the project

\begin{tabular}{|l|l|l|l|}
\hline 3 & Promoters & $\begin{array}{l}\text { Supporter and promoters of } \\
\text { the project }\end{array}$ & Internal stakeholders \\
\hline 4 & Opponents & $\begin{array}{l}\text { Opponents of the project } \\
\text { through active or passive } \\
\text { opposition or non-committed } \\
\text { activities }\end{array}$ & $\begin{array}{l}\text { community representatives, local residents, } \\
\text { environmentalists, general public, } \\
\text { indigenous and aboriginal groups }\end{array}$ \\
\hline
\end{tabular}

Categorization of Stakeholders based on role in the project

\begin{tabular}{|c|c|c|c|}
\hline 5 & $\begin{array}{l}\text { Category based } \\
\text { on functional } \\
\text { role }\end{array}$ & $\begin{array}{l}\text { Grouping according to } \\
\text { functional position in the } \\
\text { project management activities. } \\
\text { These can be community } \\
\text { actors, business actors, } \\
\text { government actors, upstream } \\
\text { stakeholders, } \\
\text { stakeholders, external } \\
\text { stakeholders, upstream } \\
\text { stakeholders group, invisible } \\
\text { stakeholders. }\end{array}$ & $\begin{array}{l}\text { Client, government agencies, customers, } \\
\text { contractor, suppliers, sponsors, local } \\
\text { community members, media, NGOs, } \\
\text { lobbying organizations, }\end{array}$ \\
\hline \multicolumn{4}{|c|}{ Categorization of Stakeholders based on extent of behavior anticipation or Contract based approach } \\
\hline 6 & $\begin{array}{l}\text { Explicit } \\
\text { Stakeholders }\end{array}$ & $\begin{array}{l}\text { Stakeholders having formal } \\
\text { contracts with the project }\end{array}$ & $\begin{array}{l}\text { Sponsors, Financiers, Owners, Partners } \\
\text { and Equity holders }\end{array}$ \\
\hline
\end{tabular}


Citation: Oudah \& Almarri., Application of Blockchain Technology for Secure Data Transactions in Organizations. Australian Journal of Basic and Applied Sciences, 13(9): 54-65. DOI: 10.22587/ajbas.2019.13.9.6

\begin{tabular}{|l|l|l|l|}
\hline 7 & $\begin{array}{l}\text { Implicit } \\
\text { Stakeholders }\end{array}$ & $\begin{array}{l}\text { Stakeholders having implicitly } \\
\text { recognized contracts with the } \\
\text { project }\end{array}$ & Users, Regulators, Staff, 1st tier suppliers \\
\hline 8 & $\begin{array}{l}\text { Implicitly } \\
\text { recognized } \\
\text { Stakeholders }\end{array}$ & $\begin{array}{l}\text { Stakeholders having implicitly } \\
\text { unrecognized contracts with } \\
\text { project }\end{array}$ & $\begin{array}{l}\text { Government, community, unions, 2nd tier } \\
\text { suppliers, relevant NGOs, local } \\
\text { government }\end{array}$ \\
\hline 9 & $\begin{array}{l}\text { Unknown } \\
\text { Stakeholders }\end{array}$ & $\begin{array}{l}\text { Stakeholders with ambiguous } \\
\text { roles in project management } \\
\text { activities }\end{array}$ & $\begin{array}{l}\text { Trade associations, interest groups, public } \\
\text { and overseas regulators, 3rd tier suppliers }\end{array}$ \\
\hline
\end{tabular}

\begin{abstract}
Research Gap
The research study of Jing \& Jian (2014) only considered employees and clients of the organization as its stakeholders for project management. While the research by Aaltonen (2010) took into account external stakeholders in the analysis. Thus, the exact constituency of organizational stakeholders is not constant for all the researches. The study of Jing \& Jian (2014) demonstrated the influence of relationship among stakeholders on the performance of the projects. However, the study lacked holistic approach in analyzing the roles played by various stakeholders in project management processes. In general, the number of research studies on the roles and responsibilities of stakeholders in organizational project management is limited. Moreover, the number of studies drops to a non-existent level with respect to roles and responsibilities of stakeholders in exploratory research practices of organizational project management. In the view of exponential technological transformation, research and development are imperative for organizational sustainability and growth. Understanding the roles and responsibilities of stakeholders is thus pertinent for effective exploratory research, which is scant in the academic field. To bridge this gap and contribute to the literature, the present study analyses the roles and responsibilities of stakeholders with relation to exploratory research in project management of multinational companies.
\end{abstract}

\title{
RESEARCH METHOD
}

This research will use a mixed-methods methodology. Mixed methods in the research context can be described as the process where both qualitative and quantitative data are gathered, analyzed and interpreted to reach at the research objectives. A single study or multiple studies can be undertaken to investigate the research problem or the underlying phenomenon. This method of research has both analytical and philosophical bearings in assumptions and inquiry. Combination of both qualitative and quantitative methods enables better understanding of the research issues. This research approach is the extension of both inductive and deductive research approaches where either qualitative or quantitative data are collected. The primary objective of mixed research method is to utilize the effective features of both the approaches while minimizing their limitations (Onwuegbuzie, Leech \& Colins, 2012).

Research design in this study elaborates the technique and strategies to be followed for data collection, analysis, and interpretation to address the research objectives. It can be termed as the layout of overall plans necessary for research conduction. The research design also defines various components of the study for coherent and logical research flow. It also ensures the adequate description of research type, data collection method and study respondents. Some of the various research designs are descriptive research, exploratory research, explanatory research, experimental research etc. (Salkind, 2010). The present study employs exploratory research design. Exploratory research focuses on investigation on research objectives for enhanced understanding of research phenomenon. Fundamental variables associated with the research study are identified and their characteristics are analyzed in this research design. Ideally this research design is followed when limited information exists about the research subject. In-depth information about the research subject is collected in this research design through various data collection mediums. Formulating research design is another name of this method.

Both primary and secondary data were collected and used in the present research study. Primary data collection method involves the collection of raw data. Most of the time, the researcher is directly involved in the data collection process. Experimentation, surveys, interviews and observations are various ways of collecting primary data. Both qualitative and quantitative information can be gathered through primary data collection. For the present study, primary data was collected through a set of mixed questionnaires containing both quantitative and qualitative questions, which were distributed among the study respondents. The study focuses on exploratory research processes employed in project management in multinational companies. Therefore, the population for this study is people working in project management related activities in multinational companies. The representative sample thus were around 500 employees of 10 multinational companies, 50 respondents from each company. All Multinational companies are operating in the United Arab Emirates.

Sampling is the process based upon which the respondents of any research study are selected from the entire population. The procedure of sampling and the selection of respondents is dependent on sampling methodology selected for the study. There are two sampling methods: Probability sampling and Non-probability sampling. Probability sampling uses equal number of participants from each population universe. Stratified sampling, cluster sampling, simple random sampling and systematic sampling are some of the examples of probability sampling. Non-probability sampling enables the researcher to select the sample 
size and respondents as per own discretion. Judgmental sampling method which is a non-probability sampling method was used to determine the multinational companies for this study. Random sampling method was used to select respondents from each chosen company which is a probability sampling method of respondent selection.

Secondary data collection method involves the accumulation of information through indirect sources. The researcher is not involved in direct data collection process rather uses the data already collected and analyzed by others. Past research papers, journals, company reports, government reports and publications are part of secondary data gathering process. For the present research, secondary data were collected through organizational reports of selected multinational companies.

The collected data are of both quantitative and qualitative in nature. Thus, two types of analysis will be carried out on the gathered data. Quantitative data were analyzed using various statistical tests such as simple percentage analysis, correlation coefficient analysis and graphical analysis using SPSS software. This is part of analytical analysis. Qualitative data were analyzed using thematic analysis where themes were determined from the responses of study respondents.

Prior permissions were taken from the respective authorities of the selected companies for data collection. The participation of respondents was on voluntary basis. The respondents had a clear idea about the research objectives before giving their responses. The respondents had the opportunity to withdraw from the research whenever they liked or felt uncomfortable. Personal information and responses of the respondents are kept confidential.

\section{DATA ANALYSIS}

For the sake of this paper, the data analysis of one multinational company is presented.

\section{Personal Profile of the Respondents}

Age: From the table we conclude that out of 50 respondent, 44\% are $45-60$ years in aged, 32\% are more than 60 years and $24 \%$ are below 40 years.

Table 4: Age frequencies

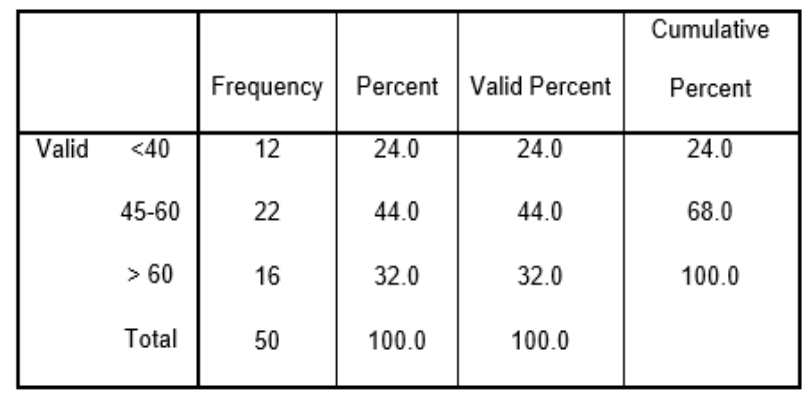

Gender: From the table, we conclude that out of 50 respondents, 2 responses are missing, 52\% are male and $44 \%$ are female.

Table 5: Gender frequencies

\begin{tabular}{|cc|c|c|c|c|}
\hline & & Frequency & Percent & Valid Percent & $\begin{array}{c}\text { Cumulative } \\
\text { Percent }\end{array}$ \\
\hline Valid & & 2 & 4.0 & 4.0 & 4.0 \\
& Female & 22 & 44.0 & 44.0 & 48.0 \\
& Male & 26 & 52.0 & 52.0 & 100.0 \\
& Total & 50 & 100.0 & 100.0 & \\
\hline
\end{tabular}

Educational qualification: From the table, we conclude that out of 50 respondent, 2 are missing, $56 \%$ are graduates, and $20 \%$ are postgraduates and undergraduates each.

Table 6: Education level. 


\begin{tabular}{|ll|l|l|l|l|}
\hline & & & & Cumulative \\
& & Frequency & Percent & Valid Percent & Percent \\
\hline Valid & 2 & 4.0 & 4.0 & 4.0 \\
& Graduate & 28 & 56.0 & 56.0 & 60.0 \\
Postgraduates & 10 & 20.0 & 20.0 & 80.0 \\
Undergraduate & 10 & 20.0 & 20.0 & 100.0 \\
Total & 50 & 100.0 & 100.0 & \\
\hline
\end{tabular}

Annual income: From the table, we conclude that out of 50 respondents, 2 are missing, 40\% have 10000-20000 AED, 24\% have 20000-50000 AED, 28\% have 5000 - 10000 AED and 4\% have above 50000 AED Annual income.

Table 7: Annual income

\begin{tabular}{|c|c|c|c|c|}
\hline & Frequency & Percent & Valid Percent & $\begin{array}{l}\text { Cumulative } \\
\text { Percent }\end{array}$ \\
\hline $\begin{array}{l}\text { 10000-20000 AED } \\
20000-50000 \text { AED } \\
5000-10000 \text { AED } \\
\text { Above } 50000 \text { AED } \\
\text { Total }\end{array}$ & $\begin{array}{l}2 \\
20 \\
12 \\
14 \\
2 \\
50\end{array}$ & $\begin{array}{l}4.0 \\
40.0 \\
24.0 \\
28.0 \\
4.0 \\
100.0\end{array}$ & $\begin{array}{l}4.0 \\
40.0 \\
24.0 \\
28.0 \\
4.0 \\
100.0\end{array}$ & $\begin{array}{l}4.0 \\
44.0 \\
68.0 \\
96.0 \\
100.0\end{array}$ \\
\hline
\end{tabular}

Total years of work experience: From the table we concluded that out of 50 respondents, $76 \%$ have above 15 years, $16.0 \%$ have $10-15$ years and $8.0 \%$ have 5-10 years of total years of work experience.

Table 8: Total work experience

\begin{tabular}{|c|c|c|c|c|c|}
\hline & & Frequency & Percent & Valid Percent & $\begin{array}{l}\text { Cumulative } \\
\text { Percent }\end{array}$ \\
\hline Valid & $\begin{array}{l}5-10 \text { years } \\
10-15 \text { years } \\
\text { above } 15 \text { years } \\
\text { Total }\end{array}$ & $\begin{array}{l}4 \\
8 \\
38 \\
50\end{array}$ & $\begin{array}{l}8.0 \\
16.0 \\
76.0 \\
100.0\end{array}$ & $\begin{array}{l}8.0 \\
16.0 \\
76.0 \\
100.0\end{array}$ & $\begin{array}{l}8.0 \\
24.0 \\
100.0\end{array}$ \\
\hline
\end{tabular}

Total years of experience in the current organization: From the table, we conclude that out of 50 respondent, 2 are missing, 44\% have above 15 years, and 20\% have 1-5 years and 5-10 years and 12\% have 10-15 years of total years of experience in the current organization.

Table 9: Total experience in the current job

\begin{tabular}{|ll|l|l|l|l|}
\hline & & Frequency & Percent & Valid Percent & $\begin{array}{l}\text { Cumulative } \\
\text { Percent }\end{array}$ \\
\hline Valid & & 2 & 4.0 & 4.0 & 4.0 \\
& $1-5$ years & 10 & 20.0 & 20.0 & 24.0 \\
$5-10$ years & 10 & 20.0 & 20.0 & 44.0 \\
10-15 years & 6 & 12.0 & 12.0 & 56.0 \\
above 15 years & 22 & 44.0 & 44.0 & 100.0 \\
Total & 50 & 100.0 & 100.0 & \\
\hline
\end{tabular}

Q:1: What is your current position?: From the table we conclude that out of 50 respondent, 2 are not followed, $40 \%$ are team member, $12 \%$ are directors, $4.0 \%$ are program Manager, $8.0 \%$ are project Manager, $32 . \%$ are others. 
Table 11: Current position

\begin{tabular}{|c|c|c|c|c|}
\hline & Frequency & Percent & Valid Percent & $\begin{array}{l}\text { Cumulative } \\
\text { Percent }\end{array}$ \\
\hline Valid & 2 & 4.0 & 4.0 & 4.0 \\
\hline Director & 6 & 12.0 & 12.0 & 16.0 \\
\hline Other (please specify) & 16 & 32.0 & 32.0 & 48.0 \\
\hline Program Manager & 2 & 4.0 & 4.0 & 52.0 \\
\hline Project Manager & 4 & 8.0 & 8.0 & 60.0 \\
\hline Team Member & 20 & 40.0 & 40.0 & 100.0 \\
\hline Total & 50 & 100.0 & 100.0 & \\
\hline
\end{tabular}

Q:2: Please indicate your level of experience in the below-mentioned project management related positions.: From the table, we conclude that following is the response for level of experience in the mentioned project management related position.

Table 13: Level of experience in project management positions

\begin{tabular}{|c|c|c|c|c|c|c|c|}
\hline $\begin{array}{l}\text { SI. } \\
\text { No. }\end{array}$ & Position & $\begin{array}{l}\text { Not } \\
\text { Applicable }\end{array}$ & $\begin{array}{l}\text { Less } \\
\text { than } 1 \\
\text { year }\end{array}$ & $\begin{array}{lr}1 & \text { year } \\
\text { to } \quad 5 \\
\text { years }\end{array}$ & $\begin{array}{lr}5 & \text { years } \\
\text { to } & 10 \\
\text { years }\end{array}$ & $\begin{array}{l}10 \text { years } \\
\text { to } 15 \\
\text { years }\end{array}$ & $\begin{array}{l}\text { More } \\
\text { than } 15 \\
\text { years }\end{array}$ \\
\hline 1 & Team Member & 6 & 2 & 12 & 6 & 0 & 20 \\
\hline 2 & Project Manager & 14 & 2 & 3 & 2 & 6 & 8 \\
\hline 3 & Program Manager & 18 & 2 & 4 & 0 & 4 & 2 \\
\hline 4 & Director & 24 & 0 & 8 & 0 & 0 & 6 \\
\hline 5 & $\begin{array}{l}\text { Other roles } \\
\text { in project } \\
\text { management }\end{array}$ & 16 & 2 & 2 & 0 & 2 & 8 \\
\hline
\end{tabular}

Q:3: How many exploratory projects do you work on, or manage in a year? From the table we conclude that out of 50 respondents, 2 are not followed, 56.0\% have 1 and $12 \%$ have 2 and 3, $4.0 \%$ have 5 and $12 \%$ have more than 5 projects work on or manage in a year.

Table 14: Number of exploratory projects per year.

\begin{tabular}{|l|l|l|l|l|}
\hline & Frequency & Percent & Valid Percent & \begin{tabular}{l} 
Percent \\
\hline
\end{tabular} \\
\hline 1 & 2 & 4.0 & 4.0 & 4.0 \\
2 & 28 & 56.0 & 56.0 & 60.0 \\
3 & 6 & 12.0 & 12.0 & 72.0 \\
5 & 6 & 12.0 & 12.0 & 84.0 \\
more than 5 projects & 6 & 4.0 & 4.0 & 88.0 \\
Total & 2 & 12.0 & 12.0 & 100.0 \\
\hline
\end{tabular}

Q:4: What is the typical duration of exploratory projects undertaken in your organization?: From the table we conclude that out of 50, 2 are not follow, 12 have up to but less than 3 months, $20 \%$ have 6 months to 1 year, $16 \%$ have more than 1 years and $12 \%$ have 3 to 6 months duration of exploratory projects undertaken in the organization. 
Table 15: Duration of managed exploratory projects.

\begin{tabular}{|l|l|l|l|l|}
\hline & Frequency & Percent & Valid Percent & $\begin{array}{l}\text { Pumulative } \\
\text { Percent }\end{array}$ \\
\hline $\begin{array}{l}\text { Valid to but less than } 3 \\
\text { months }\end{array}$ & 24 & 48.0 & 48.0 & 48.0 \\
$\begin{array}{l}3 \text { to } 6 \text { months } \\
6 \text { months to 1 years }\end{array}$ & 6 & 12.0 & 12.0 & 60.0 \\
more than 1 year & 8 & 20.0 & 20.0 & 80.0 \\
& 2 & 46.0 & 16.0 & 96.0 \\
Total & 50 & 100.0 & 100.0 & 100.0 \\
\hline
\end{tabular}

Q:5: From the below-listed phases of projects, mark the one you are usually most involved: From the table we conclude that out of 50 respondent, 2 are not followed, $44.0 \%$ are not implementation, $36.0 \%$ are concept development, $16 \%$ are planning.

Table 16: Listed phases of projects.

\begin{tabular}{|c|c|c|c|c|}
\hline & Frequency & Percent & Valid Percent & $\begin{array}{l}\text { Cumulative } \\
\text { Percent }\end{array}$ \\
\hline Valid & 2 & 4.0 & 4.0 & 4.0 \\
\hline Concept development & 18 & 36.0 & 36.0 & 40.0 \\
\hline Implementation & 22 & 44.0 & 44.0 & 84.0 \\
\hline Planning & 8 & 16.0 & 16.0 & 100.0 \\
\hline Total & 50 & 100.0 & 100.0 & \\
\hline
\end{tabular}

What is the success rate of exploratory projects of your organization?: From the table we conclude that out of 50 respondent, 2 are not followed, $48 \%$ are successful rate of exploratory projects of organization.

Table17: the Success rate of exploratory projects.

\begin{tabular}{|c|c|c|c|c|}
\hline & Frequency & Percent & Valid Percent & $\begin{array}{l}\text { Cumulative } \\
\text { Percent }\end{array}$ \\
\hline Valid & 2 & 4.0 & 4.0 & 4.0 \\
\hline Average Success Rate & 6 & 12.0 & 12.0 & 16.0 \\
\hline Less Successful & 6 & 12.0 & 12.0 & 28.0 \\
\hline Negligible Success & 2 & 4.0 & 4.0 & 32.0 \\
\hline Successful & 24 & 48.0 & 48.0 & 80.0 \\
\hline Very Successful & 10 & 20.0 & 20.0 & 100.0 \\
\hline Total & 50 & 100.0 & 100.0 & \\
\hline
\end{tabular}

Table 18: Reliability test

\begin{tabular}{|l|l|l|}
\hline $\begin{array}{l}\text { Cronbach's } \\
\text { Alpha }\end{array}$ & $\begin{array}{l}\text { Cronbach's } \\
\text { Alpha Based on }\end{array}$ & N of Items \\
\hline
\end{tabular}


Citation: Oudah \& Almarri., Application of Blockchain Technology for Secure Data Transactions in Organizations. Australian Journal of Basic and Applied Sciences, 13(9): 54-65. DOI: 10.22587/ajbas.2019.13.9.6

\begin{tabular}{|l|l|l|}
\hline & $\begin{array}{l}\text { Standardized } \\
\text { Items }\end{array}$ & \\
\hline .902 & .904 & 50 \\
\hline
\end{tabular}

The Cronbach alpha value of reliability test is 0.902 which indicates high internal consistency of statements regarding team behavior within the exploratory project management process. And statements are more reliable.

\section{FINDINGS AND DISCUSSION}

The research study ideally discusses the working structures of the organizations that are getting highly complicated these days. The application of Project management provides the organizations with effective tools by which the financial and human resources could be properly arranged and directed to gain the objectives laid by the organizations. The research in the segment of project management will help in bringing about the innovation, execution, and performance within the required time and cost determined by the organizations. Additionally, the stakeholders also play a vital role in the establishment of project management related exploratory research and are associated with different projects at various levels and to various degrees (Tarhini, Ammar \& Tarhini, 2015). The research study also provides details about the various research methodologies like research design, research approach, etc. including conclusion and recommendations that are identified by the researcher to gather and examine the collected data in a realistic and consistent way.

To analyze the role played by various stakeholders in exploratory research in a Multinational Company, the researcher has taken a mixed methodology which investigates both the qualitative and quantitative aspects of the research study. Exploratory research design has been used as the primary data through a set of mixed questionnaires containing both quantitative and qualitative questions (Yawar \& Seuring, 2017). The sample selected for the research study consisted of about 500 employees from 10 multinational companies, 50 respondents from each company. The random sampling method was used to select respondents from each chosen company. Data analysis was carried out by using graphical analysis and SPSS tool.

By investigating the collected data, there are various facts and figures and information regarding the study has been identified by the researcher. To examine the study on the roles played by various stakeholders in Exploratory research in Multinational Companies and establish whether this preference changes with the change in the demographics of the individuals, the researcher focuses on the data that has been collected based on the personal profile of respondent (Tarhini, Ammar \& Tarhini, 2015). It showed the results that there were about $44.0 \%$ of the respondents that belong to the age group category of 45-60 of who are highly active and responsive in sharing their feedbacks and $24 \%$ respondents were below 40-year age group who didn't share their experience in the research study. While carrying out the research process based on gender it was found that about $52.0 \%$ of the respondents were males and $44 \%$ are female who shares their responses related to the study. Furthermore, to explore the data based on educational qualification it was found that about $56.0 \%$ respondents were Graduate and $20.0 \%$ of the respondents were Postgraduates and Undergraduate. While making the focus on the annual income it was found that about $40.0 \%$ of the respondents were earning 10000-20000 AED and only those earning about 5000-10000 AED formed about $28.0 \%$ of the total respondents. Furthermore, while making the focus on the total number of years of work experience it was found that about $44.0 \%$ of the respondents had an experience of above 15 years in the current organizations they are working in about 10-15 years in the current organization formed about $12.0 \%$ of the total respondents.

While making the focus on section 2 which analyzed the current position in the organization of the respondents, $12 \%$ of the respondents are directors, $4 \%$ are program managers and $8 \%$ is the project manager working in a company. To analyze various exploratory projects in work on, or managed in a year, it was found that $56 \%$ respondent's work on only one exploratory project while $12 \%$ have more than 5 exploratory projects in a year, hence it can be said that workflow in a project department and program departments were working in a good way (Sigala, 2016).

Furthermore, to analyze duration of exploratory projects undertaken in the organization, $12 \%$ have up to but less than 3 months, $20 \%$ have 6 months to 1 year, 16\% have more than 1 years and 12\% have 3 to 6 months duration of exploratory projects undertaken in organization. Hence, it can be said the duration for completing the undertaken project in the organization was a highly time-consuming process. Furthermore, to determine the involvement of people in a phase of the project the data was collected and found that there were $44 \%$ respondents are involved in the implementation phase, $36 \%$ are involved in concept development, and $16 \%$ were involved in planning phase. Hence, it can be said most of involvement in the implementation phase of the project (Sierra- García, Zorio- Grima \& García- Benau, 2015). To analyze the success rate of exploratory project in organization it was found that $48 \%$ of the respondents highly agree with the successful implementation of the project in the organization, Hence, it can be said that the rate of success of exploratory project is good in the organization. To investigate the team behavior within the exploratory project management process, Cronbach's Alpha value of reliability test was performed which showed the result to be about 0.902 . This indicated that high internal consistency of statements regarding team behavior within the exploratory project management process was found and the statements are reliable (Short, McKenny, Ketchen, Snow \& Hult, 2016).

\section{CONCLUSION}

From the above discussion, it is concluded that the demographic factor related to the gender it was found that $44.0 \%$ of the respondents who belonged to the age group of 45-60 were highly participative and provided their valuable feedback in an effective manner. This shows that this age group respondent was most participative in the functionaries of the Multinational 
companies. It was also found that respondents who had completed Graduate formed about 56.0\% of the respondents who were highly active. These respondents provided their feedbacks in an effective manner. They were found to be more responsible to conduct the different operations of the Multinational companies in a proper manner. It was found that $52.0 \%$ of the males were highly participative and provided their valuable feedback effectively. This showed that Multinational companies were highly dominated by males rather than females (Sekaran \& Bougie, 2016). It was found that the respondents about $40.0 \%$ of the respondents were earning 10000-20000 AED annually were more participative in the research study and provided their valuable feedback in an encouraging manner. This showed that they formed the most active component of the Multinational companies and playing their part in exploratory research projects (Leppäaho, Plakoyiannaki \& Dimitratos, 2016). It was found upon analyzing the duration of exploratory projects undertaken in an organization that completing the undertaken project in the organization was a highly time-consuming process. The Cronbach's Alpha value of reliability test was performed which showed the result to be about 0.902. This indicated that high internal consistency of statements regarding team behavior within the exploratory project management process was found and the statements were more reliable. This showed the participation level of the respondents in the Multinational companies regarding the roles played by various stakeholders in exploratory research (Huq, Chowdhury \& Klassen, 2016).

\section{Recommendations}

- Organizations must consider various tools and methods that are used for the conduction of exploratory research prior to conducting project management assessment in the organizations (Hair Jr, Wolfinbarger, Money, Samouel \& Page, 2015).

- The number of project management tools used, and the number of risk tools must be identified by the organizations to determine the highest direct correlation.

- The organizations must develop good relations with their stakeholders which will encourage them to invest in large proportions.

- The organizations must adopt fair audit policies to attract outside stakeholders so that the capital formation of the organization increases, and they could carry out exploratory research within the company in a proper manner (Graebner, Heimeriks, Huy \& Vaara, 2017).

\section{Limitations of the current research study}

The different sources of information were limited in nature which made it difficult for the researcher to collect relevant data in an effective manner. The researcher was found to be depended on the respondents for the collection of more information who did not seem to be participative enough. Some of the respondents actively participated and provided their valuable feedback while others did not respond with much interest (Bogers et al., 2017). Moreover, there was limited time for the conduction of the research study process in a proper manner.

\section{Future expectations}

The research was necessary to be carried out to get a better knowledge and understanding of the roles played by various stakeholders in exploratory research in Multinational Companies. The research in the field of project management will enable the organizations to move towards the creation of project originality, implementation, and presentation. This will highly impact the performance of the employees and the stakeholders will get more inclined to think for the welfare of the organization (Belal, 2016).

\section{REFERENCES}

Aaltonen, K. (2010). Stakeholder management in international projects (Doctoral Dissertation). Retrieved from http://lib.tkk.fi/Diss/2010/isbn9789526033440/

Ahmed, R., \& Anantatmula, V. S. (2017). Empirical Study of Project Managers Leadership Competence and Project Performance. Engineering Management Journal, 29(3), 189-205.

Aubry, M., Sicotte, H., Drouin, N., Vidot-Delerue, H., \& Besner, C. (2012). Organizational project management as a function within the organization. International Journal of Managing Projects in Business, 5(2), 180-194.

Belal, A. R. (2016). Corporate social responsibility reporting in developing countries: The case of Bangladesh. Routledge.

Bogers, M., Zobel, A. K., Afuah, A., Almirall, E., Brunswicker, S., Dahlander, L., ... \& Hagedoorn, J. (2017). The open innovation research landscape: Established Perspectives and Emerging Themes across Different Levels of Analysis. Industry and Innovation, 24(1), 8-40.

Cork, P. (2015). Empirical study of project management practices (Masters thesis). Retrieved from https://www.theseus.fi/bitstream/handle/10024/99970/Cork_Peter.pdf?sequence=1\&isAllowed=y

Graebner, M. E., Heimeriks, K. H., Huy, Q. N., \& Vaara, E. (2017). The process of Postmerger integration: A Review and Agenda for Future Research. Academy of Management Annals, 11(1), 1-32.

Hair Jr, J. F., Wolfinbarger, M., Money, A. H., Samouel, P., \& Page, M. J. (2015). Essentials of Business Research Methods. Routledge.

Heagney, J. (2016). Fundamentals of Project Management. Amacom.

Huq, F. A., Chowdhury, I. N., \& Klassen, R. D. (2016). Social management capabilities of multinational buying firms and their emerging market suppliers: An exploratory study of the clothing industry. Journal of Operations Management, 46, 19-37. 
Citation: Oudah \& Almarri., Application of Blockchain Technology for Secure Data Transactions in Organizations. Australian Journal of Basic and Applied Sciences, 13(9): 54-65. DOI: 10.22587/ajbas.2019.13.9.6

Jing, L., \& Jian, Y. (2014). An Empirical Study of the Importance and Uniqueness of Stakeholder Management in China. Open Journal of Business and Management, 2(04), 298.

Kwak, Y. H., \& Anbari, F. T. (2009). Analyzing project management research: Perspectives from top management journals. International Journal of Project Management, 27(5), 435-446.

Leppäaho, T., Plakoyiannaki, E., \& Dimitratos, P. (2016). The case study in family business: An analysis of current research practices and recommendations. Family Business Review, 29(2), 159-173.

Morris, P. W. (2010). Research and the future of project management. International Journal of Managing Projects in Business, $3(1), 139-146$.

Onwuegbuzie, A. J., Leech, N. L., \& Collins, K. M. (2012). Qualitative analysis techniques for the review of the literature. The qualitative report, $17(28), 1-28$.

Patanakul, P., Iewwongcharoen, B., \& Milosevic, D. (2010). An empirical study on the use of project management tools and techniques across project life-cycle and their impact on project success. Journal of General Management, 35(3), 41-66.

Project Management Institute (2004). A guide to the project management body of knowledge. 3rd ed. Newton Square: PMI.

Pucihar, K. C., Kljun, M., Mariani, J., \& Dix, A. J. (2016). An empirical study of long-term personal project information management. Aslib Journal of Information Management, 68(4), 495-522.

Salkind, N. J. (Ed.). (2010). Encyclopedia of research design (Vol. 1). Sage.

Sekaran, U., \& Bougie, R. (2016). Research methods for business: A skill building approach. John Wiley \& Sons.

Short, J. C., McKenny, A. F., Ketchen, D. J., Snow, C. C., \& Hult, G. T. M. (2016). An empirical examination of firm, industry, and temporal effects on corporate social performance. Business \& Society, 55(8), 1122-1156.

Sierra- García, L., Zorio- Grima, A., \& García- Benau, M. A. (2015). Stakeholder engagement, corporate social responsibility and integrated reporting: An exploratory study. Corporate Social Responsibility and Environmental Management, 22(5), 286304.

Sigala, M. (2016). Introduction to Part 1. In Social Media in Travel, Tourism and Hospitality (pp. 29-32). Routledge.

Siriram, R. (2018). PROJECT MANAGEMENT ASSESSMENTS (PMAs): AN EMPIRICAL STUDY. The South African Journal of Industrial Engineering, 29(1), 108-127.

Söderlund, J. (2004). Building theories of project management: past research, questions for the future. International journal of project management, 22(3), 183-191.

Tarhini, A., Ammar, H., \& Tarhini, T. (2015). Analysis of the critical success factors for enterprise resource planning implementation from stakeholders' perspective: A systematic review. International Business Research, 8(4), 25.

Yawar, S. A., \& Seuring, S. (2017). Management of social issues in supply chains: a literature review exploring social issues, actions and performance outcomes. Journal of Business Ethics, 141(3), 621-643. 